\title{
Efficacy of Four Solanum spp. Extracts in an Animal Model of Cutaneous Leishmaniasis
}

\author{
Paul Cos ${ }^{1}$, Jo Janssens ${ }^{1}$, Abel Piñón ${ }^{2}$, Osmany Cuesta-Rubio ${ }^{3}$, Arianna Yglesias-Rivera ${ }^{4}$, \\ Alexis Díaz-García ${ }^{4}$, Wagner Vilegas ${ }^{5}$ (i) and Lianet Monzote ${ }^{2, *}$ \\ 1 Laboratory of Microbiology, Parasitology and Hygiene (LMPH), Faculty of Pharmaceutical, Biomedical and \\ Veterinary Sciences, Antwerp University, 2000 Antwerpen, Belgium; paul.cos@uantwerpen.be (P.C.); \\ jokejanssens5@hotmail.com (J.J.) \\ 2 Parasitology Department, Institute of Tropical Medicine "Pedro Kouri", Havana 10400, Cuba; \\ thelma@ipk.sld.cu \\ 3 Academic Unit of Chemical Sciences and Health, Technical University of Machala, Machala 070101, Ecuador; \\ osmanycuesta@yahoo.com \\ 4 Research Department, Laboratories of Biopharmaceuticals and Chemistries Productions (LABIOFAM), \\ Havana 10400, Cuba; ariannay@ipk.sld.cu (A.Y.-R.); alediaz@ipk.sld.cu (A.D.-G.) \\ 5 UNESP—São Paulo State University, Coastal Campus of São Vicente, São Paulo 19014-020, SP, Brazil; \\ wagner.vilegas@unesp.br \\ * Correspondence: monzote@ipk.sld.cu; Tel.: +53-7-255-6312
}

Received: 27 April 2018; Accepted: 25 May 2018; Published: 5 June 2018

\begin{abstract}
Background: Leishmaniasis is a complex protozoa disease caused by Leishmania genus (Trypanosomatidae family). Currently, there have been renewed interests worldwide in plants as pharmaceutical agents. In this study, the in vivo efficacy of Solanum spp. is assessed in an L. amazonensis BALB/c mice model for experimental cutaneous leishmaniasis. Methods: Animals were infected with $5 \times 10^{6}$ metacyclic promastigotes and 30-day post-infection, a treatment with $30 \mathrm{mg} / \mathrm{kg}$ of Solanum extracts or Glucantime ${ }^{\circledR}$ (GTM) was applied intralesionally every four days to complete 5 doses. Results: Neither death nor loss of weight higher than $10 \%$ was observed. All the tested extracts were able to control the infection, compared with the infected and untreated group. Solanum havanense Jacq. extract showed the highest efficacy and was superior $(p<0.05)$ to GTM. Solanum myriacanthum Dunal., S. nudum Dunal. and S. seaforthianum Andr. extracts demonstrated a similar effect $(p>0.05)$ to GTM. An increase of IFN- $\gamma(p<0.05)$ was displayed only by animals treated with $S$. nudum compared to the group treated with a vehicle, while no differences $(p>0.05)$ were observed for IL-12. Conclusions: In vivo effects of Solanum extracts were demonstrated, suggesting that this genus could be further explored as a new antileishmanial alternative.
\end{abstract}

Keywords: Leishmania amazonensis; cutaneous leishmaniasis; BALB/c mice; Solanum havanense; Solanum myriacanthum; Solanum nudum; Solanum seaforthianum

\section{Introduction}

Leishmaniasis is a protozoal disease caused by more than 20 Leishmania species, belonging to Trypanosomatidae family. The parasite affects approximately 12 million people in 98 countries throughout the world [1,2]. The clinical manifestations are diverse and may range from ulcerative skin lesions and mucosal infections to visceral forms [3,4]. Presently, there is no vaccine available against leishmaniasis, and prophylactic measures for cutaneous leishmaniasis (CL) are ineffective [5,6].

Antimony compounds are a first-line drug treatment for leishmaniasis, including sodium stibogluconate and meglumine antimoniate. Drugs, such as miltefosine, liposomal amphotericin $\mathrm{B}$, pentamidine and paromomycin, have also been used to treat this disease. However, severe adverse 
effects, high cost and drug resistance have hampered the treatment outcome of leishmaniasis [2,7]. During the last decades, there is a renewed interest worldwide in plants as pharmaceuticals [8], including search of new antileishmanial drugs [9,10].

In a previous study, Solanaceae plant extracts were evaluated for their antileishmanial activity. Solanum extracts displayed in vitro significant antileishmanial activities, particularly the ethanol extracts from the leaves of S. havanense Jacq. 1760, S. myriacanthum Dunal. 1813, S. nudum Dunal. 1816 and S. seaforthianum Andr. 1808 [11]. In this study, the in vivo efficacy of the extracts was studied in a BALB/c mice model infected with L. amazonensis. The effects on interferon gamma (IFN- $\gamma$ ) and interleukin 12 (IL-12) concentrations were also assessed.

\section{Materials and Methods}

\subsection{Parasite}

Leishmania amazonensis MHOM/77BR/LTB0016 strain was kindly provided by the Department of Immunology from Oswaldo Cruz Foundation, Brazil. Parasites were maintained in lesions on footpads of BALB/c mice, routinely isolated and cultivated as promastigotes at $26{ }^{\circ} \mathrm{C}$ in Schneider's Complete Medium, which consisted of Schneider medium (Sigma-Aldrich, St. Louis, MO, USA), $10 \%$ heat-inactivated fetal bovine serum (Sigma-Aldrich) and $100 \mu \mathrm{g}$ of streptomycin/mL-100 U of penicillin/mL (Sigma-Aldrich).

\subsection{Plant Extracts}

Samples of four species from Solanum genus identified by the taxonomist Victor Fuentes were used [11]. General characteristics, including voucher number, collection date and geographic area are listed in Table 1. The leaves of each plant were dried at $40{ }^{\circ} \mathrm{C}$ during 3 days, manually crushed (15-30 g) and afterwards, solid-liquid extractions were carried out by maceration at room temperature for 7 days with a mixture of EtOH: $\mathrm{H}_{2} \mathrm{O}(9: 1, v: v)$. After 3, 5 and 7 days, supernatants were collected with a fresh solvent added on days 3 and 5 , respectively. On day 7 , the three individual extractions were combined (3,5 and 7 days). The total extract was concentrated under a reduced pressure at $40^{\circ} \mathrm{C}$ in a rotoevaporator, subsequently lyophilized and dissolved in dimethylsulfoxide (DMSO) (BDH, Poole, England) at $20 \mathrm{mg} / \mathrm{mL}$.

Table 1. General characteristics of plants from Solanum genus used in this study.

\begin{tabular}{|c|c|c|c|c|}
\hline Plants Species & Locality $^{1}$ & Collection Date & Voucher Specimen ${ }^{2}$ & In Vitro Activity ${ }^{3}$ \\
\hline S. havanense & $\begin{array}{c}\text { Guira de Melena, } \\
\text { Artemisa }\end{array}$ & October, 2010 & ROIG-4834 & $\begin{array}{c}\mathrm{IC}_{50}=13.6 \mu \mathrm{g} / \mathrm{mL} \\
\mathrm{CC}_{50}=268.4 \mu \mathrm{g} / \mathrm{mL} \\
\mathrm{SI}=20\end{array}$ \\
\hline S. myriacanthum & $\begin{array}{l}\text { Bahia Honda, } \\
\text { Artemisa }\end{array}$ & July, 2010 & ROIG-4821 & $\begin{array}{c}\mathrm{IC} 50=11.2 \mu \mathrm{g} / \mathrm{mL} \\
\mathrm{CC} 50=86.6 \mu \mathrm{g} / \mathrm{mL} \\
\mathrm{SI}=8\end{array}$ \\
\hline S. nudum & $\begin{array}{c}\text { Bahia Honda, } \\
\text { Artemisa }\end{array}$ & July, 2010 & ROIG-4822 & $\begin{array}{c}\mathrm{IC}_{50}<6.25 \mu \mathrm{g} / \mathrm{mL} \\
\mathrm{CC}_{50}=115.0 \mu \mathrm{g} / \mathrm{mL} \\
\text { SI }>18\end{array}$ \\
\hline S. seaforthianum & $\begin{array}{c}\text { Santiago de las } \\
\text { Vegas, La Habana }\end{array}$ & July, 2010 & ROIG-4815 & $\begin{array}{c}\mathrm{IC}_{50}<6.25 \mu \mathrm{g} / \mathrm{mL} \\
\mathrm{CC}_{50}=194.3 \mu \mathrm{g} / \mathrm{mL} \\
\mathrm{SI}>31\end{array}$ \\
\hline
\end{tabular}

${ }^{1}$ Municipality and province of Cuba where plants were collected; ${ }^{2}$ Herbarium name: ROIG-Herbarium of Experimental Station of Medicinal Plants “Dr. Juan Tomás Roig”, Cuba; ${ }^{3}$ Data from Monzote et al. 2016 [11]. IC 50 : concentration of drug that caused $50 \%$ of growth inhibition of L. amazonensis amastigotes. $\mathrm{CC}_{50}$ : concentration of drug that caused $50 \%$ of mortality of peritoneal macrophage from BALB/c. SI: selectivity index $\left(\mathrm{CC}_{50}\right.$ macrophage $/ \mathrm{IC}_{50}$ amastigotes). 


\subsection{Reference Drugs}

A pentavalent antimonial based on meglumine antimoniate, i.e., Glucantime ${ }^{\circledR}$ (GTM) (Rhône-Poulenc Rorer, Mexico City, Mexico), was dissolved in sterile distilled water at $30 \mathrm{mg} / \mathrm{mL}$ and used as a reference drug.

\subsection{Animals}

The Ethics Committee from the Institute of Tropical Medicine Pedro Kouri, Havana, Cuba, (Number 14-12) approved the protocol for the animal experiments. Healthy female BALB/c mice with a body weight between 20 and $22 \mathrm{~g}$ were obtained from the National Centre of Laboratory Animals Production (CENPALAB, Cuba). Animals were maintained according to "Guideline on the Care and Use of Laboratory Animals". Ethical approval code: CEI-IPK 14-12, Date of approval: 25 September 2012.

\subsection{Infection and Treatment}

On Day 0 , the BALB/c mice were infected with $50 \mu \mathrm{L}$ of parasite suspension containing $5 \times 10^{6}$ metacyclic promastigotes suspended in a sterile saline solution (SSS). The animals were injected subcutaneously in the right footpads. On day 30 post-infection (p.i.), the mice were randomly divided into seven different groups with eight animals in each group, which were weighted as a group. Then, the treatment was initiated with $50 \mu \mathrm{L}$ of each Solanum extract or GTM at a final dose of $30 \mathrm{mg} / \mathrm{kg}$ dissolved in a mixture of SSS:DMSO (7:3, v:v). The products were injected intralesionally every 4 days at the infection site. A total of 5 doses were administrated to the BALB/c mice. In parallel, a control group (infected and untreated) and an infected and vehicle-treated group (SSS:DMSO (7:3, v:v)), using the same treatment regimen, were also included.

\subsection{Evaluation of Toxicity and Disease Progression after Treatment}

The mice were observed daily, and death was recorded from the beginning of the treatment. The body weight of each group and the progression of the lesion size (by measuring infected and non-infected footpad swelling using a dial calliper) were weekly monitored from day 30 p.i. until day 74 p.i. (week 4 p.i. until week 10 p.i., respectively). On day 45 p.i. and day 74 p.i. (week 6 p.i. and week 10 p.i., respectively), three animals of each group were sacrificed using cervical dislocation, and the parasite burden in the infected area was determined. A sample of the lesion was excised and weighted, and a microtiter method was used [12]. Parasite burden was calculated as the logarithm of the positive dilution divided by the lesion weight.

\subsection{Cytokine Measurement}

In addition, on day 45 p.i., three samples of each animal group were obtained from the infected area. Tissues were homogenized in a lytic buffer, containing $1 \%$ of a Protease Inhibitor Cocktail (104 mM 4-(2-aminoethyl)benzenesulfonyl fluoride hydrochloride or AEBSF, $80 \mu \mathrm{M}$ Aprotinin, $4 \mathrm{mM}$ Bestatin, 1.4 mM E-64, 2 mM Leupeptin and 1.5 mM Pepstatin A), 1M Tris, 0.5 M EDTA, $1 \mathrm{M} \mathrm{NaCl}$, $100 \mathrm{mM}$ DTT and NP-40 (BD Biosciences, San Diego, CA, USA), and centrifuged at 14,000 rpm for $30 \mathrm{~min}$. The supernatants of the samples were collected, and the presence of the cytokines IFN $-\gamma$ (Cat. $\mathrm{N}^{\circ}$ : 555138) and IL-12 (Cat. $\mathrm{N}^{\circ}$ : 555165) were measured by an ELISA assay using pairs of monoclonal antibodies (BD OptEIA ${ }^{\mathrm{TM}}$; BD Biosciences, San Diego, CA, USA). The procedure was performed according to the manufacturer's instructions.

\subsection{Statistical Analyses}

Data related to body weight, lesion size, parasite burden and cytokine concentration were collected in Microsoft Office Excel 2010 as a database, and afterwards, statistical analysis was performed. Moreover, the variation of body weight with respect to the start of the treatment was calculated. 
When the variation was higher than $10 \%$, toxicity of the products should be considered. The data concerning the lesion progression and the parasite burden were analyzed with a variance test, followed by the Post Hoc Test (LDS test or planned comparison). Comparison of cytokine concentration was determined with the Mann-Whitney test. In all cases, $p$-values $<0.05$ were considered statistically significant, and analyses were performed using a Statistical Windows Program (Release 4.5, StatSoft, Inc., New York, NY, USA, 1993). Finally, reduction of infection in percent related with disease control was calculated in each case, taking into account the lesion size and the parasite burden of the treated animals with extracts, a vehicle or GTM compared to the untreated control group on day 74 p.i. (week 10 p.i.).

\section{Results}

In the animals treated with the Solanum extracts, neither death nor loss of body weight higher than $10 \%$ was observed. The follow-up of the body weight for the different groups is shown in Table 2.

Table 2. Variation of body weight (\%) of the animal groups infected with L. amazonensis and treated with Solanum extracts, a vehicle or a reference drug.

\begin{tabular}{ccccccc}
\hline \multirow{2}{*}{ Groups } & \multicolumn{5}{c}{ Variation of Body Weight (\%) } \\
\cline { 2 - 6 } & $\mathbf{5}$ w.p.i. & $\mathbf{6}$ w.p.i. & $\mathbf{7}$ w.p.i. & $\mathbf{8}$ w.p.i. & $\mathbf{9}$ w.p.i. & $\mathbf{1 0}$ w.p.i. \\
\hline S. havanense & 0.1 & 2.6 & -2.7 & -0.6 & 2.8 & 6.1 \\
S. myriacanthum & -0.1 & 0.0 & -2.0 & -1.9 & -1.6 & -0.8 \\
S. nudum & 1.0 & -0.2 & -2.0 & -1.9 & -0.3 & 0.8 \\
S. seaforthianum & -1.2 & -2.6 & -4.6 & -4.4 & -4.0 & -1.5 \\
GTM $^{2}$ & -2.3 & -2.9 & -3.9 & -4.7 & -3.9 & -4.5 \\
Vehicle $^{3}$ & -1.6 & -2.4 & -4.4 & -3.1 & -4.1 & -1.3 \\
Control $^{4}$ & 0.3 & 6.9 & 2.5 & 0.3 & 2.8 & 1.8 \\
\hline
\end{tabular}

w.p.i.: weeks post-infection. ${ }^{1}$ Positive number represents increase of body weight and negative number means decrease of body weight with respect to week 4 p.i. (Start of the treatment); ${ }^{2}$ GTM: Glucantime ${ }^{\circledR}$ - reference drug;

${ }^{3}$ Vehicle: Saline solution:dimethylsulfoxide $(7: 3, v: v) .{ }^{4}$ Control: Infected and untreated mice.

Four weeks after the infection of the BALB/c mice with L. amazonensis, skin lesions at the inoculation site were visible, and the lesion size was similar $(p>0.05)$ in all the animals (Figure 1A). During the experiment, the two control groups showed a clear disease progression, and no significant lesion size (Figure $1 \mathrm{~A})$ differences $(p>0.05)$ were observed between the untreated mice and the mice treated with a vehicle.

When the lesion size was analysed (Figure 1A), S. havanense was the most effective extract to resolve the parasite infection and was significantly better $(p<0.05)$ compared with GTM, and the vehicle-treated and the untreated groups. The animals treated with $S$. myriacanthum also demonstrated a positive effect, showing a smaller lesion size compared with GTM, although the lesion size difference did not differ significantly $(p>0.05)$. In contrast, the animals treated with $S$. nudum and S. seaforthianum extracts showed the biggest lesion size difference $(p<0.05)$ compared with GTM, although at the end of the experiment (week 9 p.i. and week 10 p.i.), significant differences $(p<0.05)$ were observed in comparison with the control animals.

In addition to the lesion size, the parasite burden in the infected sites was also determined (Figure 1B). In this paper, all the cultured tissues were positive after microscopic examination, due to the presence of mobile promastigotes. Nevertheless, $S$. havanense was superior, showing a significantly lower parasite burden $(p<0.05)$, compared with GTM and the untreated animals at week 6 p.i. and week 10 p.i. This was also the case for the animals treated with $S$. myriacanthum. However, the mice treated with $S$. nudum and $S$. seaforthianum only showed a smaller parasite burden $(p<0.05)$ after 10 weeks p.i. compared with the other experimental groups. The efficacy of the treatment with S. havanense was clearly visible at the end of the experiment (Figure 2). 

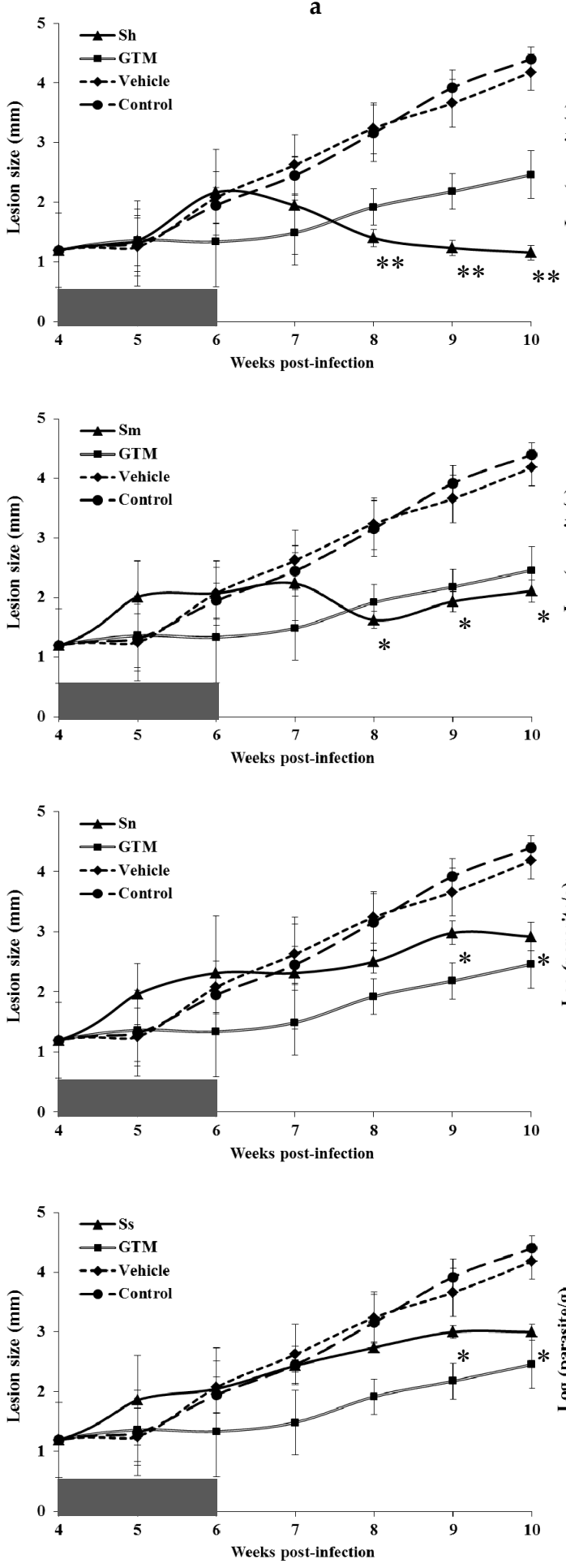

b

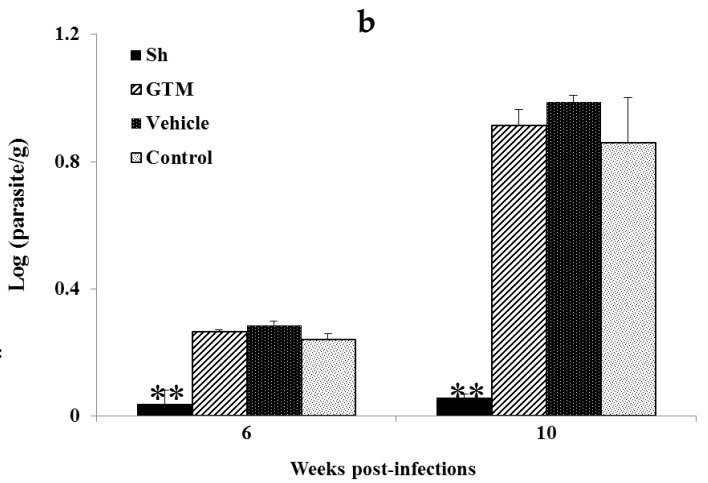

- Sm

QGTM

w Vehicle

øControl

(1)

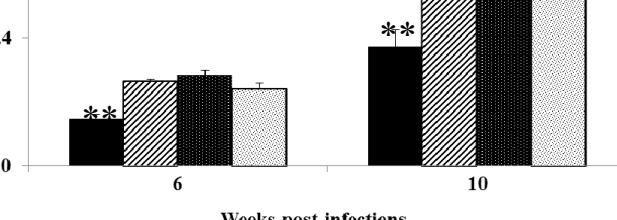

$\mathbf{m n}$

๑GTM

w Vehicle

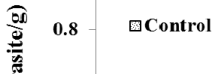

0.4

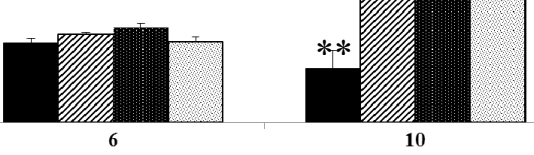

Weeks post-infections

- Ss

פGTM

- Vehicle

口Control

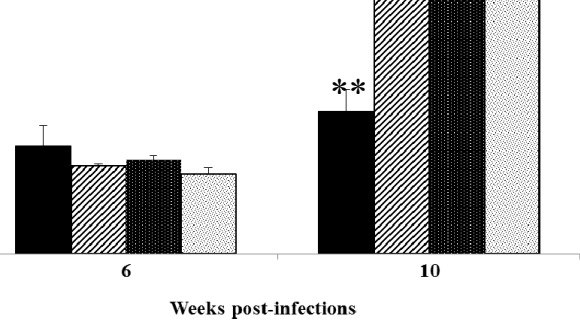

Figure 1. Effect of Solanum extracts on BALB/c mice infected subcutaneously with $5 \times 10^{6}$ promastigotes of $L$. amazonensis in the footpad. The results were expressed as mean \pm standard deviation. Treatment was started after 4 weeks p.i. Five doses were administered by intralesional route each 4 days. Glucantime ${ }^{\circledR}$ (GTM) and extracts from S. havanense (Sh), S. myriacanthum (Sm), S. nudum (Sn) and S. seaforthianum (Ss) were administered at a dose of $30 \mathrm{mg} / \mathrm{kg}$. (a) Lesion size; and (b) parasite burden. Vehicle: $50 \mu \mathrm{L}$ of saline solution:dimethylsulfoxide $(7: 3, v: v)$; control: infected and untreated mice. * Statistically significant difference $(p<0.05)$ compared with the vehicle and the control group. ** Statistically significant difference $(p<0.05)$ compared with GTM, the vehicle and the control group. 


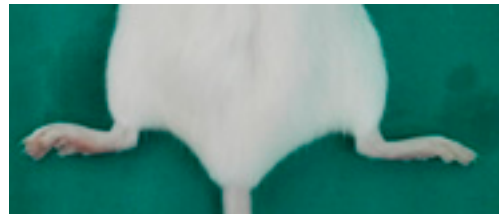

(a)

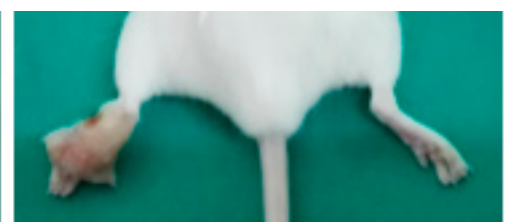

(b)

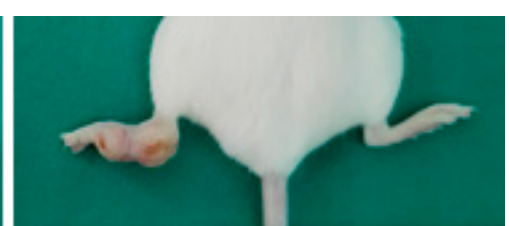

(c)

Figure 2. Pictures of footpads from BALB/c mice infected with L. amazonensis at 10 weeks p.i. (a) Animal treated with extract from $S$. havanense; (b) untreated animal; and (c) animal treated with GTM.

Finally, the reduction of infection in the treated groups compared to the untreated animals was summarized in Table 3, which displayed direct evidence on the resolution of infection according previous results at the end of experiment (10 weeks p.i.). The higher reduction of infection could be associated with the animals treated by $S$. havanense.

Table 3. Reduction of infection (\%) of the animal groups infected with L. amazonensis and treated with Solanum extracts, a vehicle or a reference drug.

\begin{tabular}{ccc}
\hline \multirow{2}{*}{ Groups } & \multicolumn{2}{c}{ Reduction of Infection (\%) } \\
\cline { 2 - 3 } & Lesion Size & Parasite Burden \\
\hline S. havanense & 73.7 & 93.6 \\
S. myriacanthum & 52.0 & 56.8 \\
S. nudum & 33.6 & 80.8 \\
S. seaforthianum & 31.8 & 49.9 \\
GTM $^{1}$ & 44.1 & 0 \\
Vehicle $^{2}$ & 5.0 & 0
\end{tabular}

${ }^{1}$ GTM: Glucantime ${ }^{\circledR}$-reference drug; ${ }^{2}$ Vehicle: Saline solution:dimethylsulfoxide $(7: 3, v: v)$.

To preliminarily evaluate the induction of Th1 response, the concentrations of IFN- $\gamma$ and IL-12 were measured at week 6 p.i. in the lesion site of mice. In general, the treatments did not cause a significant effect on the cytokine concentrations compared with the control group (Figure 3). However, the animals treated with $S$. nudum showed statistically higher concentrations of IFN- $\gamma$ $(p<0.05)$ compared to the vehicle-treated and the control groups. In the case of IL-12, slightly lower concentrations were observed for the extracts, but they did not differ $(p>0.05)$ from the vehicle-treated animals.
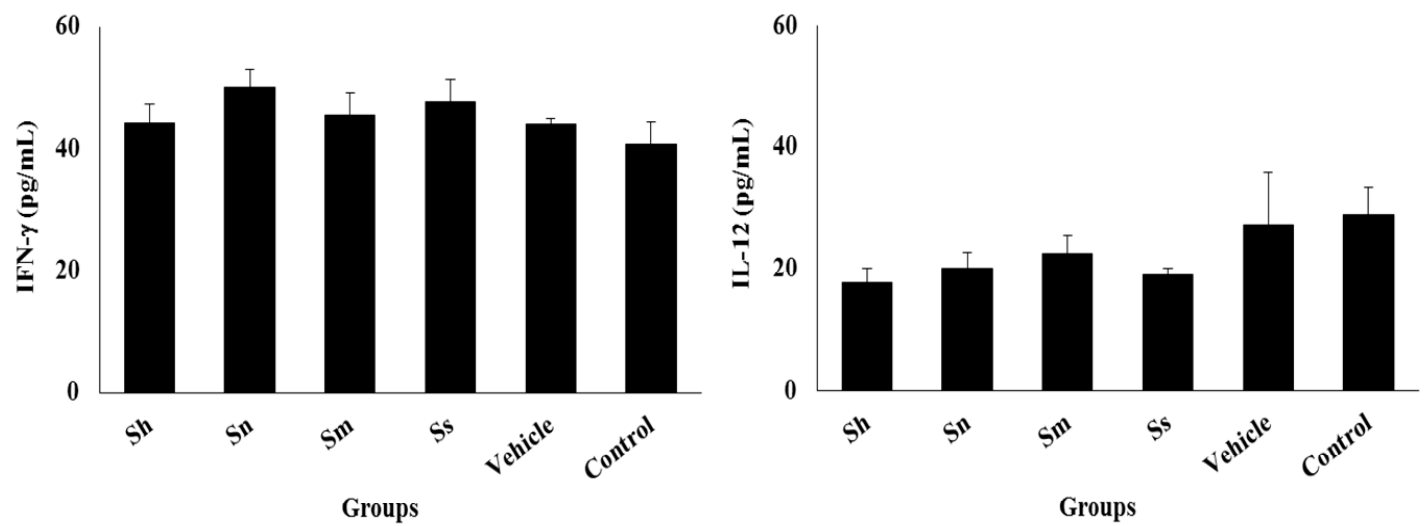

Figure 3. IFN- $\gamma$ and IL-12 production in infected areas of BALB/c with L. amazonensis. The results were expressed as mean \pm standard deviation. * Statistically significant difference $(p<0.05)$ compared with the vehicle-treated and the control groups. 


\section{Discussion}

Due to the unsatisfactory current treatments of leishmaniasis, there is a strong need for new and effective antileishmanial drugs. In the search for innovative therapeutics, natural products are still an important source. Solanum genus is the most representative and largest genus from Solanaceae with more than 1700 species, which are mainly distributed in tropical regions. Many species belonging to this genus possess various pharmacological activities, including antibacterial [13], antifungal [14], antiviral [15] and antiparasitic activities [16,17]. In particular, antiprotozoal activity against the Leishmania parasite of the Solanum spp. has been previously reported [11,18-20]. In this study, we have evaluated four Solanum species for their activity against L. amazonensis in a BALB/c mouse infection model, which is known to be highly susceptible to L. amazonensis infection [21]. The extracts and the reference compound were administered through an intralesional injection, because it is more effective than an oral route [22]. In addition, a dose of $30 \mathrm{mg} / \mathrm{kg}$ was used, which is a dose close to the recommended dose for the reference drug, GTM, and previous positive results with other natural products $[23,24]$.

In general, all the tested extracts were able to control the infection compared with the control and the vehicle-treated groups. Solanum genus was characterized by steroidal alkaloid saponins [25], although phytochemical studies of Solanum species have also reported a wide variety of different chemical entities, such as carotenoids, phenolic compounds [26], sesquiterpenoids [27] and coumarins [28]. All these different compounds displayed antileishmanial activity [10]. Moreover, havanine [29], acetyl ethiolin and solamarine [30] have been identified in S. havanense, while tumacones and tumacosides have been isolated from S. nudum [16].

Our animal experiments showed that only $S$. havanense extracts were superior to GTM; while S. myriacanthum, S. nudum and S. seaforthianum demonstrated a similar effect to GTM. A promising in vitro effect cannot always be correlated with a good in vivo effect, mainly due to the ADME properties of a compound. In the in vitro study, S. nudum and S. seaforthianum showed the lowest IC50-values against intracellular amastigotes (Table 1) [11], but when assessed in vivo, the group treated with these extracts exhibited a larger lesion size and a higher parasite burden compared with $S$. havanense and S. myriacanthum. The first possible explanation is related to a low absorption and a low distribution of compounds into subcutaneous tissues, since the compounds needed to be distributed to the tissues before interacting with the parasites. In this study, we selected intralesional administration because it is more probable that a major percent of active compounds arrive at parasite locations in comparison with oral, intraperitoneal or intravenous administration. However, compounds should be dissolved in subcutaneous tissues, be distributed among cells, enter into macrophage and other probably infect cells, such as dendritic cells, and finally perform the effect inside parasitophore vacuoles. Differences in the ability of compounds to dissolve, distribute and come across membrane are possible, and could be one reason of difference in activity observed. Secondly, the in vivo effects of the extracts could be associated with indirect actions, such as antioxidant, anti-inflammatory or immunostimulatory activities. To the best of our knowledge, previous pharmacological investigations of $S$. havanense have not been reported, while Solanum lycopersicum L. showed an antioxidant activity [31] and Solanum melongena L. possessed anti-inflammatory effects [32].

In summary, although a positive antileishmanial effect in the murine model was observed in the four tested extracts, activities were caused by different active principles. Currently, no identification of compounds has been carried out because the extracts are very complex mixtures of compounds. Previously, a metabolomics study using ultra-performance liquid chromatography with mass spectrometry (UPLC-MS) displayed variations in qualitative and semi-quantitative chemical compositions. In this sense, an extensive mass list in a chemical profile of extracts corresponding to a wide variety of metabolites was appreciated [11]. Then, in order to identify probable antileishmanial compounds, a bio-guide fractionation of extracts and standardization of respective chemical profile are needed.

Considering that effective defense towards Leishmania strains, including L. amazonensis, depends strictly upon T (Th1) cells and macrophage activating cytokines $[33,34]$, we measured the production 
of IFN- $\gamma$ and IL-12. These cytokines initiated and/or drove the basic antileishmanial Th1 profile and played particularly prominent experimental roles. In the present study, we showed that only the S. nudum extract was able to slightly increase IFN- $\gamma$ production, which is a key cytokine for protection against many infections caused by intracellular parasites [35-37]. The mechanism by which IFN- $\gamma$ acts against intracellular parasites is through the classical activation of macrophages. Inducible nitric oxide synthase (iNOS) will be expressed, leading to the production of nitric oxide (NO) and consequently to the death of the parasites [38]. It has been previously postulated that L. amazonensis causes a strong subversion of the host immune response [39], whereby immunomodulating compounds could be used in disease control. The previously demonstrated direct antileishmanial activity of S. nudum [11] and the increase of IFN- $\gamma$ can open further work to study the probable immunomodulator activity of the extract at different time after treatment and cytokines profile as a ratio (Th1/Th2). Probably, the delayed effect of $S$. nudum extracts that was observed during the last weeks of the in vivo experiments could be the result of its immunomodulatory effect. In addition, it is known that a protective immunity against all species of Leishmania is mediated by an IL-12-driven Th1 response to result in an increased IFN-g production [40]. Therefore, IL-12 is important for primary Th1 immunity against Leishmania to maintain a local Th1 response during infection [41,42]. However, in our study, lower IL-12 levels were observed in mice, including in the animals treated with S. nudum. Probably, the lower concentrations of IL-12 could be result of measurement time.

Thus, we can suggest that the antileishmanial effect observed by $S$. nudum could be responsible for a direct parasite action and influenced by a probable immunomodulator activity, which should be demonstrated. Usually, the parasite load determined the level of cytokines and decreases with the infection, which was in correspondence with reduction of infection to animals treated with S. nudum that showed $80.8 \%$ of resolution of parasite burden. Nevertheless, an effective elimination of L. amazonensis parasites in BALB/c mice needed additional neutralization of both IL-10 and IL-4 cytokines in order for IFN $\gamma$ to reach a threshold activity needed for parasite killing [43]. Similar results were discussed by Barroso and collaborators related to the immunomodulator effect of Z-100-a polysaccharide obtained from Mycobacterium tuberculosis_evaluated in the same model of CL in BALB/c mice infected with L. amazonensis [40].

In scientific literatures, some studies have divulged that leishmanicidal plants extracts can potentiate key cellular immune responses, probably due to plant secondary metabolites, which have proven to be coherent in the quest for more efficacious and less toxic antileishmanial drugs [44-46]. Then, plant-derived products have become a focal point for discovery of antileishmanials with leishmanicidal and immunomodulatory properties. In this sense, we cited per example: the extract from Artemisia annua L. [47], Asparagus racemosus Willd. [45] and Kalanchoe pinnata (Lam.) Pers. [48].

\section{Conclusions}

To conclude, our previous in vitro results of the Solanum extracts [11] and their in vivo effects showed that this genus could be considered as a potential antileishmanial alternative. Future determination of the chemical composition and standardization of the extracts are strongly suggested, which could be explored as a new alternative in the treatment of leishmaniasis, in particular, based on S. havanense-derived products. In addition, basic studies on the mechanisms of action and immunomodulatory activity were addressed.

Author Contributions: O.C.-R. and W.V. conceived the study and carried out collection of vegetal materials and extractions. P.C. and L.M. designed the experiments. J.J., A.P. and L.M. performed the biological assays; while A.Y.-R. and A.D.-G. determinated the cytokine profile. P.C., L.M. and J.J. wrote the article. All the authors reviewed the manuscript.

Acknowledgments: The present study was supported by the Ministry of Higher Education (MES) from Cuba and Conselho Nacional de Capacitação de Aperfeiçoamento de Pessoal de Nível Superior (CAPES) from Brazil through grant CAPES/MES 183/12. In addition, special thanks are given to Victor Fuentes Fiallo for botanical classification of the plant material. 
Conflicts of Interest: The authors declare no conflicts of interest. The founding sponsors had no role in the design of the study; in the collection, analyses, or interpretation of data; in the writing of the manuscript; and in the decision to publish the results.

\section{References}

1. Feasey, N.; Wansbrough-Jones, M.; Mabey, D.C.W.; Solomon, A.W. Neglected tropical diseases. Br. Med. Bull. 2010, 93, 179-200. [CrossRef] [PubMed]

2. Alvar, J.; Velez, I.D.; Bern, C.; Herrero, M.; Desjeux, P.; Cano, J.; Jannin, J.; den Boer, M. Leishmaniasis worldwide and global estimates of its incidence. PLoS ONE 2012, 7, e35671. [CrossRef] [PubMed]

3. David, C.V.; Craft, N. Cutaneous and mucocutaneous leishmaniasis. Dermat. Ther. 2009, 22, 491-502. [CrossRef] [PubMed]

4. Abebe, T.; Hailu, A.; Woldeyes, M.; Mekonen, W.; Bilcha, K.; Cloke, T.; Fry, L.; Seich, A.L.; Basatena, N.K.; Corware, K.; et al. Local increase of arginase activity in lesions of patients with cutaneous leishmaniasis in Ethiopia. PLoS Negl. Trop. Dis. 2012, 6, e1684. [CrossRef] [PubMed]

5. Genaro, O.; de Toledo, V.P.; da Costa, C.A.; Hermeto, M.V.; Afonso, L.C.; Mayrink, W. Vaccine for prophylaxis and immunotherapy, Brazil. Clin. Dermatol. 1996, 14, 503-512. [CrossRef]

6. Kedzierski, L.; Zhu, Y.; Handman, E. Leishmania vaccines: Progress and problems. Parasitology 2006, 133, S87-S112. [CrossRef] [PubMed]

7. Croft, S.L.; Seifert, K.; Yardley, V. Current scenario of drug development for leishmaniasis. Ind. J. Med. Res. 2006, 123, 399-410.

8. Newmann, D.J.; Cragg, G.M. Natural products as sources of new drugs over the last 25 years. J. Nat. Prod. 2007, 70, 461-477. [CrossRef] [PubMed]

9. Rocha, L.G.; Almeida, J.; Macedo, R.O.; Barbosa-Filho, J.M. A review of natural products with antileishmanial activity. Phytomedicine 2005, 12, 514-535. [CrossRef] [PubMed]

10. Singh, N.; Mishra, B.B.; Bajpai, S.; Singh, R.K.; Tiwari, V.K. Natural product based leads to fight against leishmaniasis. Bioorg. Med. Chem. 2013, 22, 18-45. [CrossRef] [PubMed]

11. Monzote, L.; Jiménez, J.; Cuesta-Rubio, O.; Márquez, I.; Gutiérrez, Y.; da Rocha, C.Q.; Marchi, M.; Setzer, W.N.; Vilegas, W. In vitro assessment of plants growing in Cuba belonging to Solanaceae family against Leishmania amazonensis. Phytother. Res. 2016, 30, 1785-1793. [CrossRef] [PubMed]

12. Buffet, P.A.; Sulahian, A.; Garin, Y.J.F.; Nassar, N.; Derouin, F. Culture microtitration a sensitive method for quantifying Leishmania infantum in tissues of infected mice. Antimicrob. Agents Chemother. 1995, 39, 2167-2168. [CrossRef] [PubMed]

13. Mabona, U.; Viljoen, A.; Shikanga, E.; Marston, A.; Van Vuuren, S. Antimicrobial activity of southern African medicinal plants with dermatological relevance: From an ethnopharmacological screening approach to combination studies and the isolation of a bioactive compound. J. Ethnopharmacol. 2013, 148, 45-55. [CrossRef] [PubMed]

14. Pinto, F.C.L.; Uchoa, D.E.A.; Silveira, E.R.; Pessoa, O.D.L.; Braz-Filho, R.; Silva, F.N.; Theodoro, P.N.E.T.; Espíndola, L.S. Antifungal glycoalkaloids, flavonoids and other chemical constituents of Solanum asperum. Quim. Nov. 2011, 34, 284-288. [CrossRef]

15. Chataing, B.; Buitrago, C.N.; Concepción, J.L.; Usubillaga, A. Estudio clínico de la efectividad de extractos alcaloideos obtenidos de los frutos del Solanun americanum Miller sobre el herpes simplex herpes zoster y herpes genitalis. Rev. Fac. Farm. 1996, 32, 15-28.

16. López, M.L.; Vommaro, R.; Zalis, M.; de Souza, W.; Blair, S.; Segura, C. Induction of cell death on Plasmodium falciparum asexual blood stages by Solanum nudum steroids. Parasitol. Int. 2010, 59, 217-225. [CrossRef] [PubMed]

17. Miranda, M.A.; Magalhães, L.G.; Tiossi, R.F.J.; Kuehn, C.C.; Oliveira, L.G.R.; Rodrigues, V.; McChesney, J.D.; Bastos, J.K. Evaluation of the schistosomicidal activity of the steroidal alkaloids from Solanum lycocarpum fruits. Parasitol. Res. 2012, 111, 257-262. [CrossRef] [PubMed] 
18. Miranda, M.A.; Tiossi, R.F.J.; da Silva, M.R.; Rodrigues, K.C.; Keuhn, C.C.; Rodrigues, L.G.; Albuquerque, S.; McChesney, J.D.; Lezama-Davila, C.M.; Isaac-Marquez, A.P.; et al. In vitro Leishmanicidal and Cytotoxic Activities of the glycoalkaloids from Solanum lycocarpum (Solanaceae) Fruits. Chem. Biodivers. 2013, 10, 642-648. [CrossRef] [PubMed]

19. Paik, D.; Das, P.; De, T.; Chakraborti, T. In vitro anti-leishmanial efficacy of potato tuber extract (PTEx): Leishmanial serine protease(s) as putative target. Exp. Parasitol. 2014, 146, 11-19. [CrossRef] [PubMed]

20. Mothana, R.A.; Al-Musayeib, N.M.; Al-Ajmi, M.F.; Cos, P.; Maes, L. Evaluation of the In Vitro Antiplasmodial, Antileishmanial, and Antitrypanosomal Activity of Medicinal Plants Used in Saudi and Yemeni Traditional Medicine. eCAM 2014, 2014, 1-7. [CrossRef]

21. De Siqueira Paladi, C.; Pimentel, I.A.; Katz, S.; Cunha, R.L.; Judice, W.A.; Caires, A.C.; Barbiéri, C.L. In vitro and in vivo activity of a palladacycle complex on Leishmania (Leishmania) amazonensis. PLoS Negl. Trop. Dis. 2012, 6, e1626. [CrossRef]

22. Gomes de Lima, S.C.; Teixeira, M.J.; Gonçalves, J.E.; de Morais, S.M.; Torres, A.F.; Braga, M.A.; Oliveira, R.; Rodrigues, R.; Pinheiro, G.M.; Costa, A.; et al. In Vitro and In Vivo Leishmanicidal Activity of Astronium fraxinifolium (Schott) and Plectranthus amboinicus (Lour.) Spreng against Leishmania (Viannia) braziliensis. BioMed. Res. Int. 2014, 2014, 1-7. [CrossRef] [PubMed]

23. García, M.; Scull, R.; Satyal, P.; Setzer, W.N.; Monzote, L. Chemical Characterization, Antileishmanial Activity and Cytotoxicity Effects of the Essential Oil from Leaves of Pluchea carolinensis (Jacq.) G. Don. (Asteraceae). Phytother. Res. 2017, 31, 1419-1426. [CrossRef]

24. Monzote, L.; Piñón, A.; Scull, R.; Setzer, W.N. Chemistry and leishmanicidal activity of the essential oil from Artemisia absinthium from Cuba. Nat. Prod. Commun. 2014, 9, 1799-1804. [PubMed]

25. Lu, Y.; Luo, J.; Kong, L. Steroidal alkaloid saponins and steroidal saponins from Solanum surattense. Phytochemistry 2011, 72, 668-673. [CrossRef] [PubMed]

26. Rodríguez, E.; Mariutti, L.R.B.; Mercadante, A.Z. Carotenoids and Phenolic Compounds from Solanum sessiliflorum, an Unexploited Amazonian Fruit, and Their Scavenging Capacities against Reactive Oxygen and Nitrogen Species. J. Agric. Food Chem. 2013, 61, 3022-3029. [CrossRef] [PubMed]

27. Yao, F.; Song, Q.; Zhang, L.; Li, G.; Dai, S. Three new cytotoxic sesquiterpenoids from Solanum lyratum. Phytochem. Lett. 2013, 6, 453-456. [CrossRef]

28. Yin, H.; Li, J.H.; Li, J.; Li, B.; Chen, L.; Tian, Y.; Liu, S.; Zhang, T.; Dong, J. Four new coumarinolignoids from seeds of Solanum indicum. Fitoterapia 2013, 84, 360-365. [CrossRef] [PubMed]

29. Basterechea, M.; Preiss, A.; Coll, F.; Voigt, T.D.; Mout, J.L.; Adams, G. Havanine-a steroidal alkaloid glycoside from Solanum havanense. Phytochemistry 1984, 23, 2057-2059. [CrossRef]

30. Basterrechea, M.J.; Ferrer, A.; Calzadilla, M.; Rodríguez, M.; Navarro, A.E.; Pérez, C. Algunos componentes esteroidales del Solanum havanense Jacq. Cienc. Ergo Sum 2000, 7, 126-128.

31. Li, H.; Deng, Z.; Liu, R.; Young, C.; Zhu, H.; Loewen, S.; Tsao, R. Characterization of Phytochemicals and Antioxidant Activities of a Purple Tomato (Solanum lycopersicum L.). J. Agric. Food Chem. 2011, 59, 11803-11811. [CrossRef] [PubMed]

32. Sun, J.; Gu, Y.; Su, X.; Li, M.; Huo, H. Anti-inflammatory lignanamides from the roots of Solanum melongena L. Fitoterapia 2014, 98, 110-116. [CrossRef] [PubMed]

33. Murray, H.W. Clinical and experimental advances in treatment of visceral leishmaniasis. Antimicrob. Agents Chemother. 2001, 45, 2185-2197. [CrossRef] [PubMed]

34. Murray, H.W.; Delph-Etienne, S. Role of endogenous gamma interferon and macrophage microbicidal mechanisms in host response to chemotherapy in experimental visceral leishmaniasis. Infect. Immun. 2000, 68, 288-293. [CrossRef] [PubMed]

35. Suzuki, Y.; Orellana, M.A.; Schreiber, R.D.; Remington, J.S. Interferon-gamma: The major mediator of resistance against Toxoplasma gondii. Science 1988, 240, 516-518. [CrossRef] [PubMed]

36. Torrico, F.; Heremans, H.; Rivera, M.T.; Van, M.E.; Billiau, A.; Carlier, Y. Endogenous IFNgamma is required for resistance to acute Trypanosoma cruzi infection in mice. J. Immunol. 1991, 146, 3626-3632. [PubMed]

37. Wang, Z.E.; Reiner, S.L.; Zheng, S.; Dalton, D.K.; Locksley, R.M. CD4+ effector cells default to the Th2 pathway in interferon gamma-deficient mice infected with Leishmania major. J. Exp. Med. 1994, 179, 1367-1371. [CrossRef] [PubMed]

38. Morris, S.M., Jr.; Billiar, T.R. New insights into the regulation of inducible nitric oxide synthesis. Am. J. Physiol. 1994, 266, E829-E839. [CrossRef] [PubMed] 
39. Soong, L. Subversion and utilization of host innate defense by Leishmania amazonensis. Front. Immunol. 2012, 3, 1-7. [CrossRef] [PubMed]

40. Barroso, P.A.; Marco, J.D.; Calvopina, M.; Kato, H.; Korenaga, M.; Hashiguchi, Y. A trial of immunotherapy against Leishmania amazonensis infection in vitro and in vivo with Z-100, a polysaccharide obtained from Mycobacterium tuberculosis, alone or combined with meglumine antimoniate. J. Antimicrob. Chemother. 2017, 59, 1123-1129. [CrossRef] [PubMed]

41. Ashok, D.; Schuster, S.; Ronet, C.; Rosa, M.; Mack, V.; Lavanchy, C.; Marraco, S.F.; Fasel, N.; Murphy, K.M.; Tacchini-Cottier, F.; et al. Cross-presenting dendritic cells are required for control of Leishmania major infection. Eur. J. Immunol. 2014, 44, 1422-1432. [CrossRef] [PubMed]

42. Martínez-López, M.; Iborra, S.; Conde-Garrosa, R.; Sancho, D. Batf3-dependent CD103 ${ }^{+}$dendritic cells are major producers of IL-12 that drive local Th1 immunity against Leishmania major infection in mice. Eur. J. Immunol. 2015, 45, 119-129. [CrossRef] [PubMed]

43. Tacchini-Cottier, F.; Weinkopff, T.; Launois, P. DoesT helper differentiation correlate with resistance or susceptibility to infection with L. major? Some insights from the murine model. Front. Immun. 2012, 3, 32. [CrossRef] [PubMed]

44. Chouhan, G.; Islamuddin, M.; Sahal, D.; Afrin, F. Exploring the role of medicinal plant based immunomodulators for effective therapy of leishmaniasis. Front. Immunol. 2014, 5, 193. [CrossRef] [PubMed]

45. Sachdeva, H.; Sehgal, R.; Kaur, S. Asparagus racemosus ameliorates cisplatin induced toxicities and augments its antileishmanial activity by immunomodulation in vivo. Parasitol. Int. 2014, 63, 21-30. [CrossRef] [PubMed]

46. Shakya, N.; Sane, S.A.; Gupta, S. Antileishmanial efficacy of fluconazole and miltefosine in combination with immunomodulator picroliv. Parasitol. Res. 2011, 108, 793-800. [CrossRef] [PubMed]

47. Islamuddin, M.; Chouhan, G.; Farooque, A.; Dwarakanath, B.S.; Sahal, D.; Afrin, F. Th1-biased immunomodulation and therapeutic potential of Artemisia annua in murine visceral leishmaniasis. PLoS Negl. Trop. Dis. 2015, 9, e3321. [CrossRef] [PubMed]

48. Gomes, D.C.; Muzitano, M.F.; Costa, S.S.; Rossi-Bergmann, B. Effectiveness of the immunomodulatory extract of Kalanchoe pinnata against murine visceral leishmaniasis. Parasitology 2010, 137, 613-618. [CrossRef] [PubMed] 